\title{
Analisis Kekeringan Berdasarkan Bentuklahan Di Das Bompon
}

\author{
Maulida Rahmi, M. Anggri Setiawan, Djati Mardiatno
}

Masuk: 12072019 / Diterima: 2609 2019 / Dipublikasi: 31122019

(c) 2019 Fakultas Hukum dan IImu Sosial UNDIKSHA dan IGI

\begin{abstract}
Analysis of drought vulnerability by units of landforms that vary in the assessment area. The objectives of this study are to mapping defeats using appreciation drying, and to analyze the vulnerability of drought based on landforms. The method used to map drought vulnerability that is needed by geomorphology, weighting, or scoring is given to each landform unit as an indicator used to obtain vulnerability classes. The higher the provided sign, the greater the score or award given. The results showed that the interfluve landform units and hills above the slope had a high level of drought susceptibility. High category vulnerability classes are characterized by the emergence of groundwater that is difficult to find - medium class drought susceptibility to the shape of the middle slopes of hills and hills below the hills. The form of the colluvial leg slopes and alluvial plains depends on the level of low-grade drought, and this is following the conditions found in the field, namely the emergence of groundwater that is easily found. Drought in landform units is characterized by morphological conditions and the location of springs found in buckling slopes. The use of methods for drought studies with detailed scales, both qualitatively and quantitatively, needs to be done again to find the development of appropriate techniques in analyzing drought studies from a social perspective.
\end{abstract}

Key words: Landform; Watershed; Geomorphology; Vulnerability; Drought

\begin{abstract}
Abstrak Analisis kerawanan kekeringan dipengaruhi oleh kondisi satuan bentuklahan yang bervariasi pada wilayah kajian. Tujuan dari penelitian ini adalah untuk memetakan kerawanan kekeringan menggunakan pengharkatan, dan menganalisis kerawanan kekeringan berdasarkan bentuklahan. Metode yang digunakan untuk memetakan kerawanan kekeringan yaitu pendekatan geomorfologi, pembobotan atau skoring diberikan pada setiap satuan bentuklahan sebagai indikator yang digunakan untuk menilai kelas kerawanan. Semakin besar pengaruh yang diberikan oleh indikator maka semakin besar pula skor atau pengharkatan yang diberikan. Hasil penelitian menunjukkan bahwa satuan bentuklahan interfluve dan lereng atas perbukitan memiliki tingkat kerawanan kekeringan tinggi. Kelas kerawanan kategori tinggi ditandai dengan kemunculan airtanah yang sulit ditemui. Kerawanan kekeringan kelas sedang berada pada bentuklahan lereng tengah perbukitan dan lereng bawah perbukitan. Bentuklahan lereng kaki koluvial dan dataran aluvial berada pada tingkat kekeringan kelas rendah, hal ini sesuai dengan kondisi yang ditemukan di lapangan, yaitu kemunculan airtanah yang mudah ditemui. Kekeringan pada satuan bentuklahan ditandai oleh kondisi morfologi dan lokasi ditemukannya mataair yang muncul di tekuk lereng. Penggunaan metode untuk kajian kekeringan dengan skala detail baik secara kualitatif dan kuantitatif perlu dilakukan lagi untuk menemukan perkembangan metode yang tepat dalam melakukan analisis kajian kekeringan dari segi sosial.
\end{abstract}

Kata kunci : Bentuklahan; Daerah Aliran Sungai; Geomorfologi; Kerawanan; Kekeringan

\section{Pendahuluan}

Kekeringan didefinisikan secara umum adalah kurangnya ketersediaan air untuk sementara/dalam jangka waktu tertentu. Kekeringan dapat diartikan juga

\footnotetext{
Maulida Rahmi, M. Anggri Setiawan, Djati Mardiatno Fakultas Geografi, Universitas Gadjah Mada maulida.rahmi@mail.ugm.ac.id
}

sebagai suatu keadaan dimana terjadi kekurangan air, dalam hal ini biasanya dikonotasikan dengan kekurangan air hujan (Raharjo, 2010). Dewasa ini bencana kekeringan semakin sering terjadi secara periodik. Kekeringan terjadi ketika kebutuhan air lebih besar dari ketersediaan air. Di Indonesia, kekeringan merupakan salah satu bencana yang 
dijumpai pada musim kemarau. Definisi kekeringan berbeda-beda menurut disiplin ilmu saat ini. Permasalahan utama di Daerah Aliran Sungai (DAS) Bompon adalah kurangnya ketersediaan air yang berdampak pada terjadinya kekeringan. Kekeringan yang terjadi disebabkan oleh cadangan airtanah yang tersedia tidak mampu mencukupi kebutuhan air penduduk. Faktor yang berpengaruh disebabkan oleh material tanah yang dominan clay. Sebagai konsekuensi dari material clay tidak dapat menjadi akuifer yang baik dalam meloloskan air.

Permasalahan ini juga secara langsung akan berpengaruh pada kemampuan lahan daerah tersebut Keterbatasan kondisi fisiografis lereng timur laut Gunung Agung merupakan faktor pembatas yang menyebabkan penggunaan lahan menjadi tidak optimal (Budiarta, 2014).

Kondisi morfologi yang beragam juga menjadi permasalahan unik dalam mengakses sumber air untuk memenuhi kebutuhan. Sumber air utama yang digunakan masyarakat DAS Bompon adalah mataair atau rembesan. Terdapat beberapa mataair di DAS Bompon dengan debit yang cukup relatif ketika musim hujan. Namun mataair tersebut belum dimanfaatkan secara efisien serta distribusi yang tidak merata pada setiap satuan bentuklahan yang terdapat di DAS Bompon. DAS Bompon terbagi atas enam satuan bentuklahan; interfluve, lereng atas perbukitan, lereng tengah perbukitan, lereng bawah perbukitan, lereng kaki koluvial, dan dataran aluvial. Bentuklahan sangat mempengaruhi keberadaan mataair maupun aksesibilitas sumber air. Sutikno (1989) menyebutkan pendekatan bentuklahan dapat digunakan untuk pemintakan system penyediaan air di suatu wilayah. Wilayah yang berpotensi mengalami kekeringan dicirikan oleh kondisi morfologi yang khas berupa satuan bentuklahan yang berada pada daerah perbukitan maupun pegunungan.

Fokus penelitian ini yaitu membangun metode analisis kerawanan menggunakan pendekatan geomorfologis. Dibyosaputro (2001) menyebutkan bahwa pendekatan geomorfologi dapat mengidentifikasi bahaya alam seperti gempa, bahaya aktivitas vulkanik, maupun potensi sumberdaya alam. Kekeringan sering terjadi dan setiap kejadiannya selalu dikatakan menjadi sebuah bencana. Analisis kerawanan dilakukan dengan tujuan mengkarakterisasi probabilitas yang berpotensi terjadinya suatu kejadian, misalnya kekeringan. Karakterisasi kekeringan tersebut dapat dilakukan misalnya dengan memperkirakan suatu faktor yang menghasilkan dampak dari suatu kondisi.

Mengidentifikasi sebaran daerah yang tergolong kekeringan dengan menggunakan pendekatan geomorfologi merupakan suatu strategi analisa yang masih tergolong baru, karena biasanya penelitian terkait kekeringan lahan yang sudah pernah dilakukan sebelumnya hanya memperhatikan faktor keterbatasan sumber mata air tanpa mencari tau faktor penyebab utamanya. Padahal kalau kita cermati, keterbatasan sumber mata air secara langsung dipengaruhi oleh morfologi suatu wilayah. Gradient lereng yang ada juga mencerminkan tingkat potensial ketersediaan sumber air.

Pendekatan geomorfologi yang digunakan dalam penelitian ini juga bertujuan untuk mengidentifikasi bentuklahan dengan menggunakan peta bentuklahan (tentatif). Menurut Dibyosaputro (2001) aspek penting yang perlu diperhatikan dalam menganalisis bentuklahan meliputi morfologi, struktur, dan proses yang ada dalam bentanglahan. Bentuklahan seringkali diklasifikasikan berdasarkan genesisnya. Genesis merupakan dasar klasifikasi yang fleksibel dimana proses geomorfik tercermin dalam 
bentuklahannya dan secara spasial dapat dipetakan ke dalam peta geomorfologi dengan unit area utamanya adalah bentuklahan. Pencapaian Hasil penelitian berupa pengembangan metode pendekatan geomorfologi untuk memetakan kerawanan kekeringan menggunakan skala 1:10.000 sehingga informasi yang dihasilkan merupakan informasi detil. Wang, Lettenmaier, \& Sheffield (2011) mengatakan sejumlah penelitian yang menyelidiki tentang kekeringan telah banyak dilakukan terutama pada skala regional dan global.

Berdasarkan fokus penelitian dan hasil yang diharapkan maka penelitian ini memiliki tujuan: (1) Memetakan kerawanan kekeringan menggunakan skoring, (2) Menganalisis kerawanan kekeringan berdasarkan bentuklahan.

\section{Metode}

DAS Bompon merupakan bagian dari system DAS Kodil meliputi tiga desa; Desa Kwaderan, Wonogiri, dan Margoyoso. Berada pada dua kecamatan yang berbeda; Kecamatan Kajoran dan Kecamatan Salaman, Kabupaten Magelang. Peta lokasi penelitian disajikan pada Gambar 1 Luas lahan untuk permukiman sekitar $287.747 \mathrm{~m}^{2}$ atau 28,7747 dari luas keseluruhan 300 ha. Pemilihan lokasi didasarkan pada keadaan di lapangan yaitu lokasi penelitian rentan terhadap kekeringan dan lokasi kajian memiliki luasan yang relatif kecil dengan karakteristik geomorfologi yang kompleks.
Metode penelitian yang digunakan dalam penelitian ini yaitu pemetaan kekeringan bentuklahan dengan menggunakan pendekatan bentuklahan. Pengumpulan data di lapangan diawali dengan survei berdasarkan peta turunan dari DEM dan foto udara (peta tentatif bentuklahan). Survei dengan pendekatan sidik cepat dan parsitipatif masyarakat juga dilakukan dengan tujuan mengidentifikasi dan konvergensi bukti di lapangan terkait bentuklahan. Analisis dalam penelitian ini dilakukan berdasarkan hasil survei yang menghasilkan peta bentuklahan dan peta kerawanan kekeringan berdasarkan bentuklahan. Peta kerawanan kekeringan diperoleh berdasarkan analisis kerawanan kekeringan menggunakan satuan unit bentuklahan. Analisis tersebut menggunakan aspek kajian meliputi karakteristik masing-masing unit bentuklahan yang memiliki tingkat kerawanan kekeringan yang berbeda. Parameter yang mempengaruhi karakteristik bentuklahan dikelompokkan menjadi tiga kelas dengan pemberian nilai skoring (Tabel 1). Pemberian skoring tersebut berdasarkan asumsi peneliti berdasarkan pertimbangan kondisi di lapangan. Setiap satuan bentuklahan diberikan skor berdasarkan pengaruh yang dihasilkan. Semakin besar pengaruh, maka semakin besar pula nilai yang diberikan. Semakin besar nilai yang diberikan, maka semakin besar pula tingkat kerawanannya.

Tabel. 1 Kelas Kekeringan pada Bentuklahan

\begin{tabular}{lcl}
\hline \multicolumn{1}{c}{ Bentuklahan } & Skor & \multicolumn{1}{c}{ Pertimbangan } \\
\hline Interfluve & 3 & Akses jalan, keberadaan sumur, ada tidaknya air \\
\hline Lereng atas perbukitan & 3 & Paling luas, ada yang terpisah, akses jalan, keberadaan sumur \\
\hline Lereng tengah perbukitan & 3 & Keberadaan sumur, akses jalan, keberadaan sumur \\
\hline Lereng bawah perbukitan & 2 & Keberadaan sumur, akses jalan, luas kenampakan \\
\hline Dataran Kaki Koluvial & 1 & Akses jalan, keberadaan sumur \\
\hline Dataran Aluvial & 1 & Akses jalan, keberadaan sumur \\
\hline
\end{tabular}




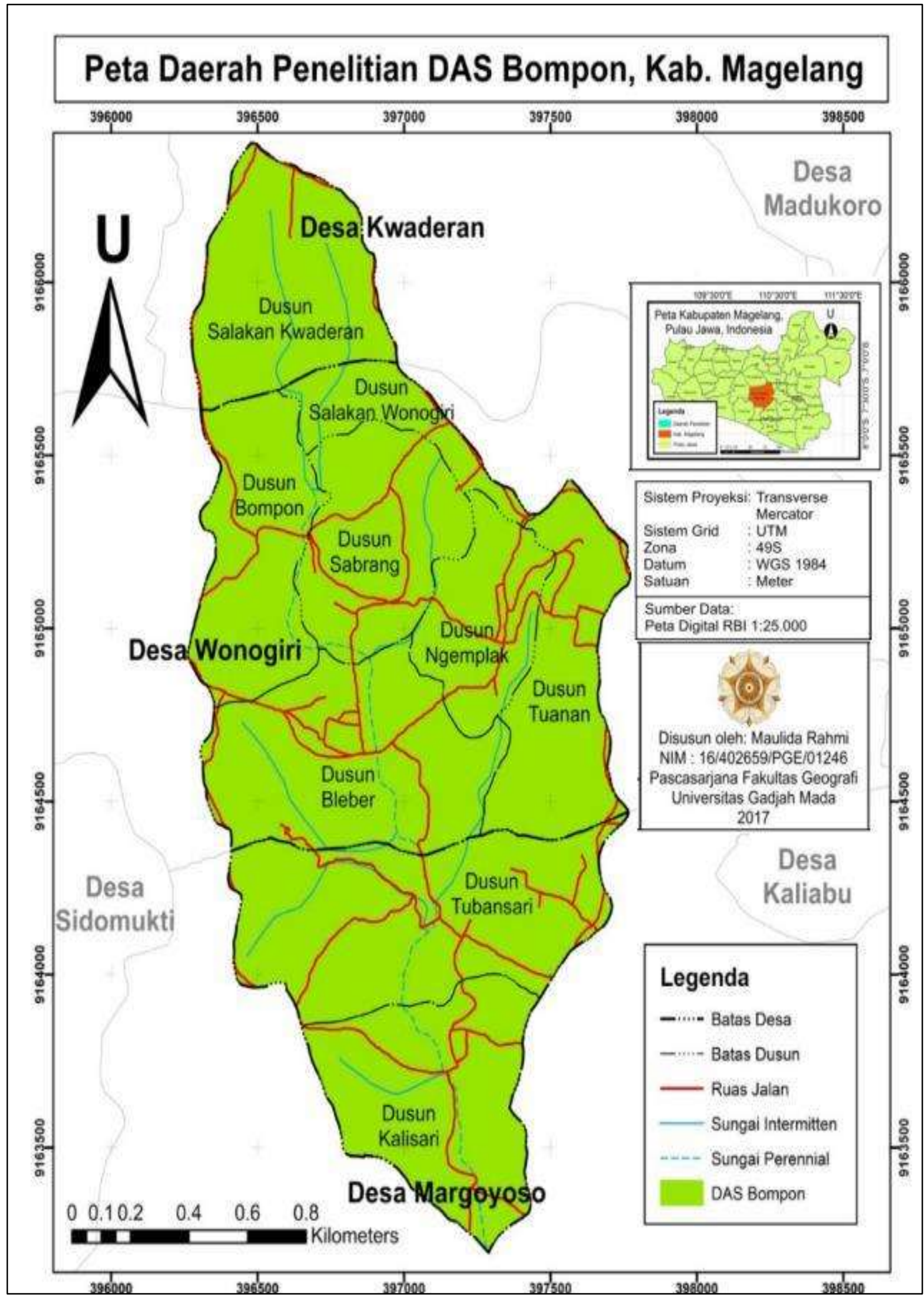

Gambar 1. Peta Lokasi Penelitian

93 | Media Komunikasi Geografi, Vol. 20, No. 2, Desember 2019: 90-100 


\section{Hasil dan pembahasan}

\section{Pemetaan Kerawanan Kekeringan}

Kekeringan dapat diidentifikasi dengan menggunakan pendekatan bentuklahan. Pendekatan ini digunakan berdasarkan beberapa penelitian sebelumnya yang menyebutkan bentuklahan memeiliki keterkaitan dengan ketersediaan airtanah. Dewasa ini, penelitian kekeringan berdasarkan berbagai indikator kekeringan (Sadri \& Burn, 2012). Indikator kekeringan efektif digunakan sebagai tolak ukur mengetahui dan menganalisis kekeringan. Beberapa indikator kekeringan dipakai dalam penelitian sebelumnya, misalnya indeks kekeringan kelembaban tanah, curah hujan terstandarisasi, dan kondisi vegetasi (Liu \& Kogan, 1996; Mishra \& Singh, 2010), perbedaan indikator yang digunakan hanya dapat mempertimbangkan satu aspek kekeringan tertentu misalnya kekeringan pertanian, meteorologi, atau hidrologi. kekeringan Kondisi kekeringan yang dialami oleh wilayah kajian berdasarkan ketersediaan airtanah. Menurut (Raharjo, 2010) satuan bentuklahan mempunyai kesamaan dalam aspek topografi, batuan induk, tanah, dan proses alam yang berlangsung sehingga kondisi permukaan lahan juga memicu terjadinya kekeringan. Penelitian yang hampir sama dilakukan oleh Puspitorukmin (2013) yang mengkaji tentang kekeringan berdasarkan bentuklahan di Daerah Istimewa Yogyakarta.

Satuan bentuklahan di DAS Bompon dianalisis berdasarkan morfologi, morfoaransemen, dan genesa dengan asumsi pada setiap bentuklahan masingmasing memiliki karakteristik yang mempengaruhi terjadinya kekeringan. Kondisi morfologi wilayah kajian sangat beragam berupa dataran berombak, bergelombang, berbukit, serta bergunung. Perbedaan morfologi suatu unit bentuklahan mempengaruhi perkembangan tanah. Perkembangan tanah pada unit satuan bentuklahan juga dapat mempengaruhi kondisi airtanah. Morfoaransemen yang terbagi ke dalam enam bagian menjadi interfluve, lereng atas perbukitan, lereng tengah perbukitan, lereng bawah perbukitan, lereng kaki koluvial, dan dataran aluvial. Temuan di lapangan memperlihatkan bahwa yang membedakan aransemen berupa kemunculan mataair seperti terlihat pada Gambar 2.

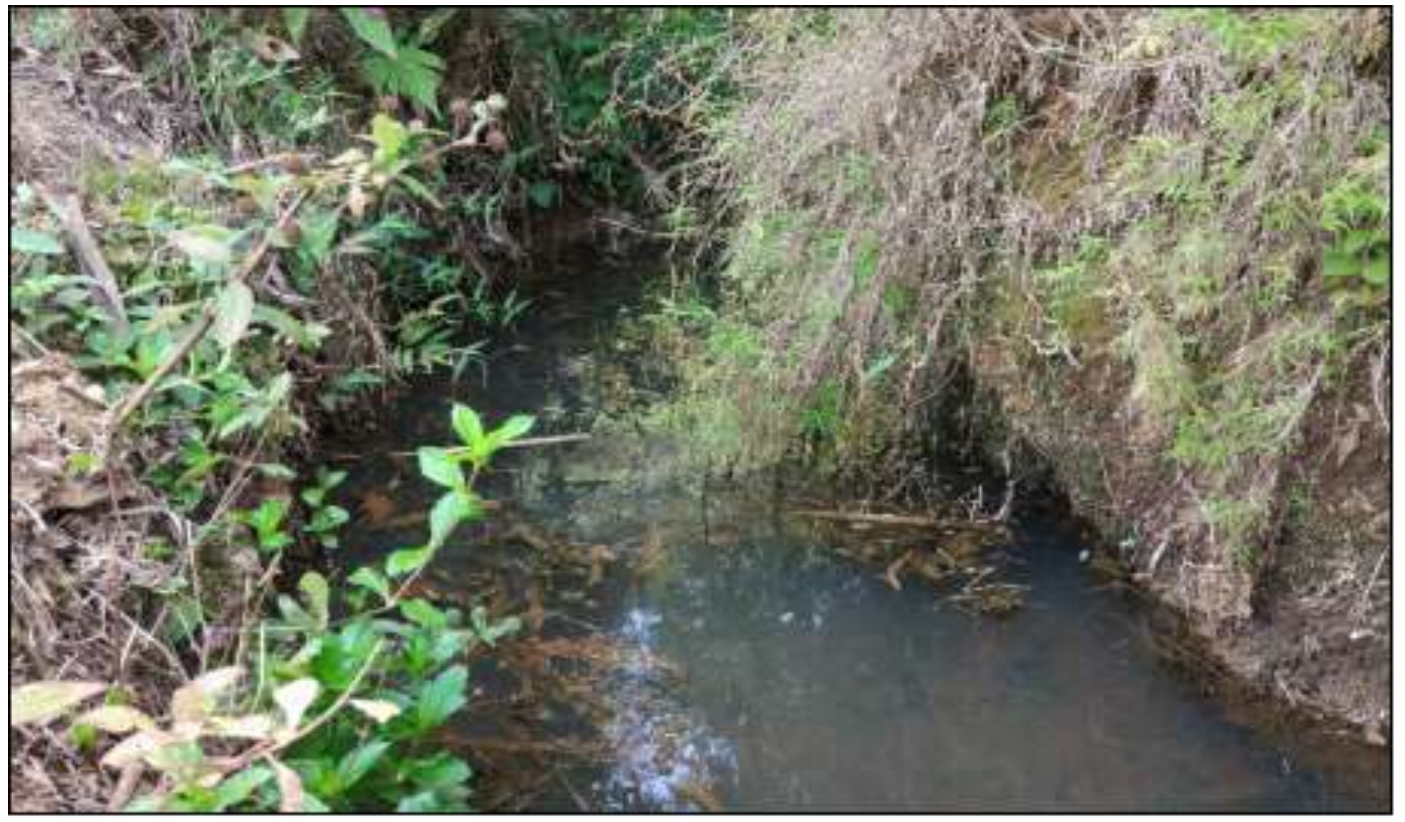

Gambar 2. Munculnya Air Pada Bagian Tekuk Lereng Sebagai Pembeda Aransemen 


\section{Genesa DAS Bompon meliputi} struktural, vulkanik, dan fluvial. Genesa struktural ditandai dengan zona residual atau interfluve sering disebut juga dengan igir perbukitan (struktural). Bentuklahan asal proses vulkanik memiliki kemiringan lereng sebesar $4^{0}-16^{0}$ dan dicirikan dengan topografi tinggi yang termasuk lereng miring hingga agak curam dengan adanya material vulkanik dan masih dipengaruhi oleh sistem vulkanik dari Gunungapi Sumbing di bagian utara maupun Gunungapi Purba Menoreh di bagian selatan. Materialnya berupa endapan abu gunungapi tersebut kemudian berkembang menjadi tanah dengan tekstur lempung lebih mendominasi. Bentuklahan fluvial berada pada kemiringan lereng sebesar $2^{0}-4^{0}$ yang termasuk landai, serta ditandai dengan terdapatnya material permukaan endapan yang terangkut melalui lereng.

Analisis bentuklahan tersebut merupakan langkah awal yang dilakukan untuk menyusun peta kerawanan kekeringan. Berdasarkan penjelasan yang telah disebutkan, maka langkah berikutnya adalah memberi pengharkatan skor atau nilai untuk setiap satuan bentuklahan yang berpotensi mengalami kekeringan. Pengharkatan dimaksudkan sebagai pemberian angka skor terhadap masingmasing kriteria dalam setiap parameter. Satuan bentuklahan adalah parameter untuk mengetahui tingkat kerawanan kekeringan di wilayah kajian. Pemberian skor ini didasarkan pada seberapa besar pengaruh satuan bentuklahan tersebut terhadap kekeringan.

Prinsip dalam pemberian skor mendasarkan pada analisa logis (logika) dan pertimbangan tertentu. Semakin tinggi pengaruh terhadap kekeringan maka skor yang diberikan semakin tinggi, semakin rendah pengaruh yang terdapat pada satuan bentuklahan terhadap kekeringan, harkat diberikan rendah pula. Pengharkatan untuk bentuklahan di wilayah kajian seperti yang dituang dalam tabel penilaian kerawanan kekeringan seperti terlihat pada Tabel 2 .

Tabel. 2 Penilaian Kekeringan

\begin{tabular}{lcc}
\hline \multicolumn{1}{c}{ Bentuklahan } & $\begin{array}{c}\text { Harkat } \\
\text { Kerawanan }\end{array}$ & Kriteria Kerawanan \\
\hline Interfluve, Lereng atas perbukitan & 3 & Tinggi \\
Lereng bawah perbukitan, Lereng tengah perbukitan & 2 & Sedang \\
Lereng kaki koluvial, Dataran Aluvial & 1 & Rendah \\
\hline
\end{tabular}

Sumber : Analisis Data Primer (2019)

Masing-masing kelas terdapat dua satuan bentuklahan dikarenakan pembagian kelas yang menjadi tiga kelas; rendah, sedang, dan tinggi. Kelas kerawanan rendah diberi harkat atau skor berupa satu, dengan asumsi dan pertimbangan berdasarkan temuan di lapangan bahwa satuan bentuklahan lereng kaki koluvial dan dataran aluvial mudah ditemui airtanah. Keberadaan sumur serta akses jalan menuju sumber air juga mudah untuk dijangkau. Kelas kerawanan sedang terdapat pada bentuklahan lereng bawah perbukitan dan lereng tengah perbukitan dengan pertimbangan keberadaan airtanah yang masih sulit ditemui dan keberadaan sumur masih belum merata serta akes jalan yang sedikit sulit, sehingga pada kelas kerawanan sedang diberi harkat dengan nilai dua. Satuan bentuklahan interfluve dan lereng atas perbukitan diberikan harkat tiga, dengan alasan pada bentuklahan ini sulit ditemukan mataair dan sumur sehingga dikatakan rawan kekeringan. 
Mataair yang ditemui di lapangan hampir keseluruhan berada pada tekuk lereng dan diperkirakan muncul karena adanya perpotongan antara muka airtanah dengan topografi permukaan tanah yang menurun. Sebaran titik mataair diperoleh di lapangan berjumlah tujuh mataair.
Mataair tersebut ditemui pada lokasi yang memiliki bentuklahan bervariasi; Lereng Tengah Perbukitan, Lereng Kaki Koluvial, Dataran Aluvial, dan Lereng Bawah Perbukitan. Distribusi mataair dan bentuklahan dapat diamati seperti terlihat pada Gambar 3.

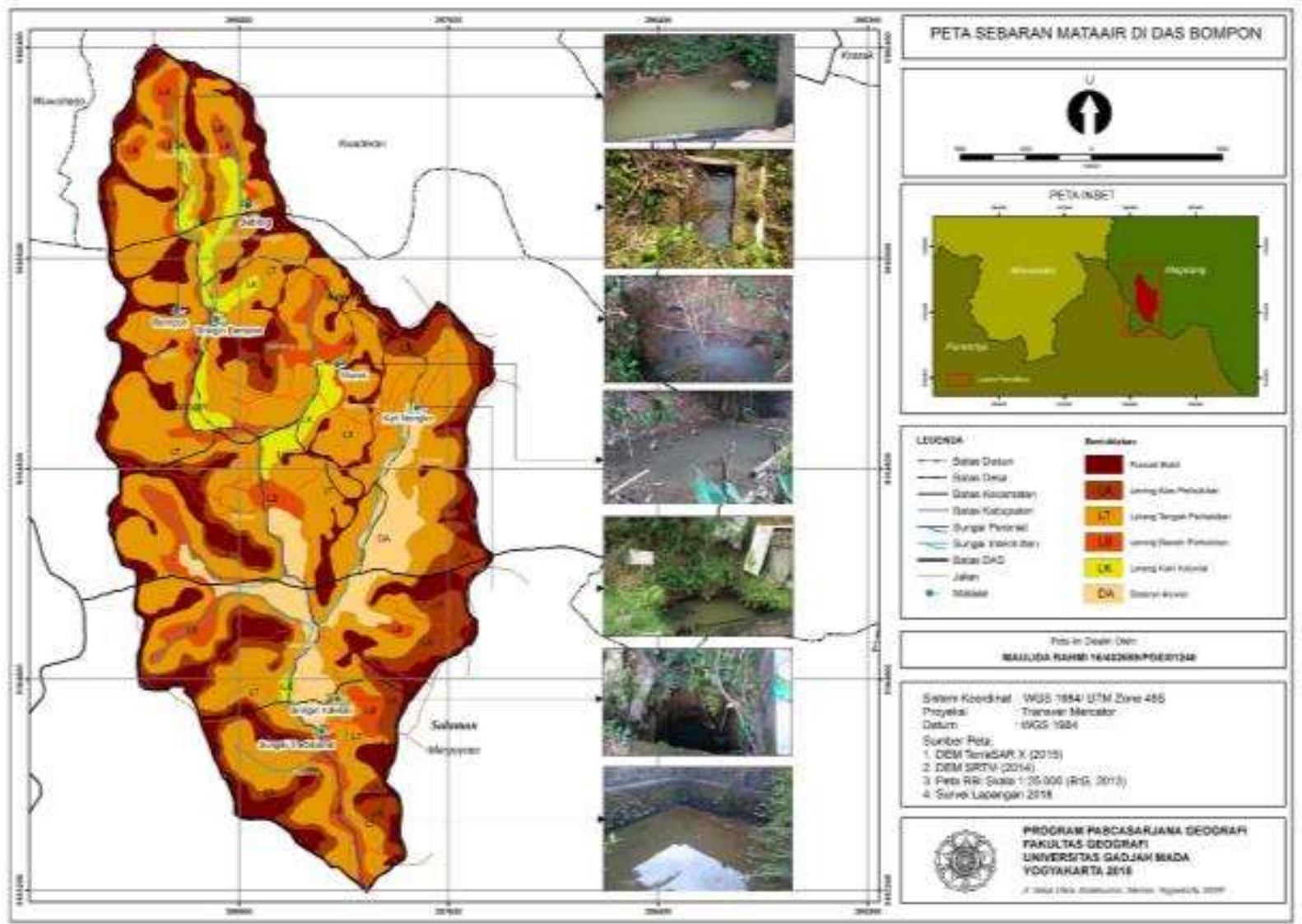

Gambar 3. Peta Persebaran Mataair Berdasarkan Bentuklahan

\section{Analisis Kerawanan Kekeringan}

Persebaran kekeringan di DAS Bompon dapat ditentukan tingkat kerawanannya dengan menggunakan pendekatan geomorfologi seperti yang telah dilakukan sebelumnya. Hasil identifikasi bentuklahan dan pengharkatan yang telah dilakukan, dispasialkan pada peta seperti pada Gambar 4. Pembuatan peta kerawanan kekeringan dengan memanfaatkan data turunan DEM dan analisis foto udara cukup efektif untuk melihat variasi keruangan daerah yang mengalami kekeringan. Hal ini sejalan dengan penelitian yang pernah dilakukan oleh Hadi (2012) yang mengemukakan bahwa penggunaan Citra Satelit Aster khususnya pada saluran 13 sangat efektif untuk menentukan tingkat kekeringan karena memiliki selisih yang paling kecil terhadap suhu permukaan. Dari peta yang telah disusun diperoleh beberapa analisis. Diketahui bahwa bentuklahan yang memiliki potensi kekeringan tinggi berada pada interfluve dan lereng atas perbukitan. Kelas potensi ini merupakan satuan bentuklahan yang memiliki ciri secara keseluruhan sangat rawan terjadi kekeringan. Satuan bentuklahan Interfluve memiliki karakteristik kelerengan curam. 
Lereng atas perbukitan memiliki karakteristik kelerengan agak curam dan bentuk lereng cembung, sangat berpengaruh pada gravitasi mengalirnya air.

Sudut lereng pada satuan bentuklahan dapat mempengaruhi kecepatan mengalirnya air. Kemiringan lereng terjal menjadikan air hujan turun menjadi aliran permukaan sehingga tidak terserap oleh tanah. Kondisi seperti ini yang menjadikan alasan sulit untuk ditemukan airtanah dan sumur pada rumah penduduk. Analisis ini sesuai dengan temuan pada penelitian terdahulu. Persentase kemiringan lereng yang besar menyebabkan air hujan yang jatuh ke permukaan tanah sebagian besar menjadi aliran permukaan dan hanya sebagian yang mampu terinfiltrasi ke dalam tanah (Puspitorukmin, 2013). Infiltrasi terjadi ketika air mampu melewati pori-pori tanah dan celah bebatuan yang ada di permukaan.

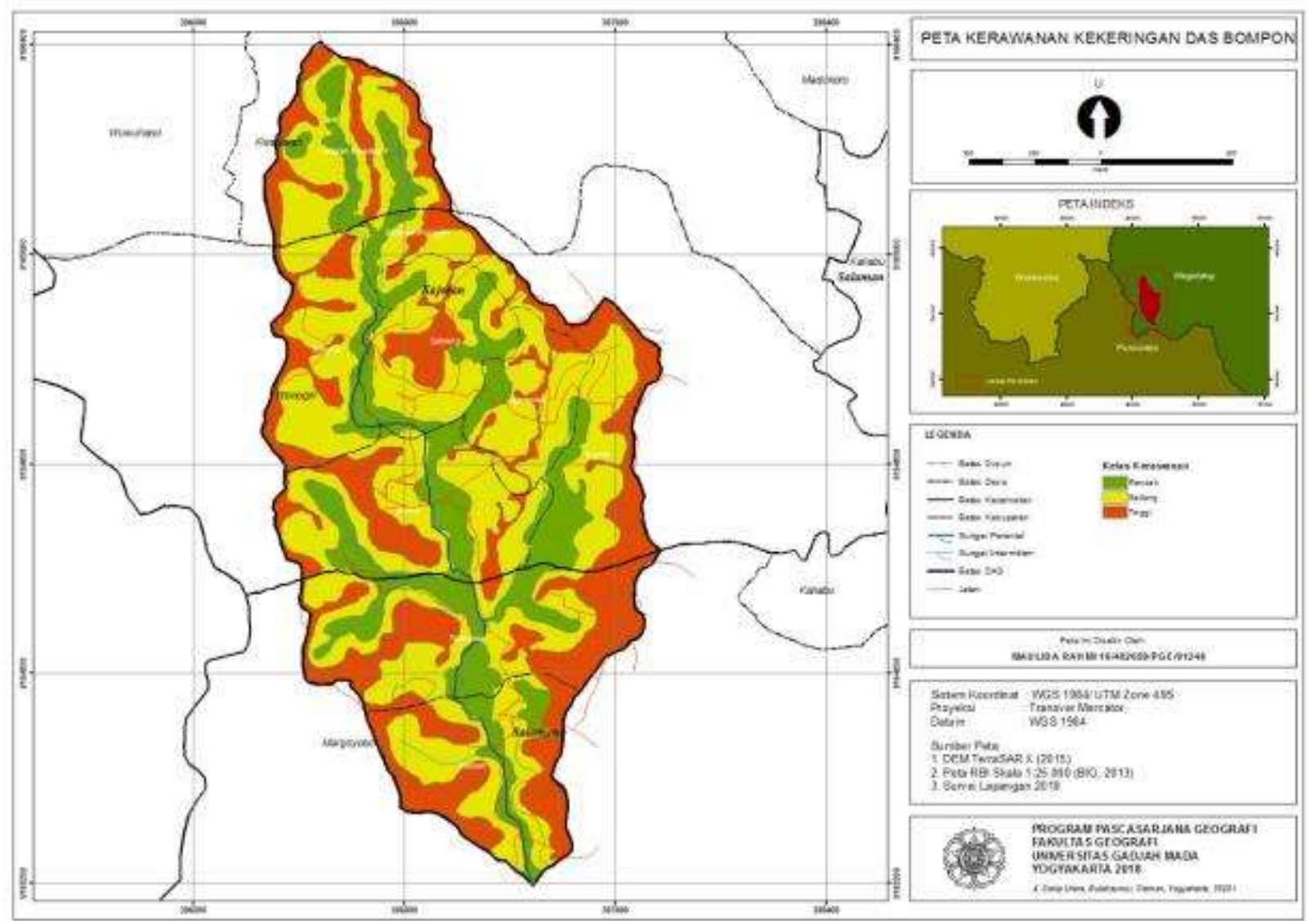

Gambar 4 Peta Kerawanan Kekeringan

Kerawanan kekeringan kelas sedang berada pada lereng tengah perbukitan dan lereng bawah perbukitan. Satuan bentuklahan tersebut merupakan bentuklahan yang kemungkinan terjadi kekeringan sedikit lebih kecil dari bentuklahan dengan kategori tinggi. Mataair mulai dapat ditemui pada satuan bentuklahan ini. Kemiringan lerengnya pun sedikit lebih landai sehingga air hujan yang jatuh sedikit lebih mudah tersimpan dan meresap ke dalam tanah. Asumsi tersebut ditandai dengan keterdapatan beberapa sumur pada rumah masyarakat setempat yang bermukim pada bentuklahan ini.

Lereng kaki koluvial dan dataran aluvial berada pada kelas yang mengalami kerawanan kekeringan kategori rendah bahkan hampir tidak pernah mengalami 
kekeringan atau masa krisis air. Memiliki drainase yang cukup baik dan kemiringan lereng yang datar. Hal serupa juga ditandai oleh sumur dan airtanah yang mudah diperoleh. Lereng yang datar menerima pasokan air dari daerah hulu serta mampu menampung air. Dataran aluvial DAS Bompon memiliki kedalaman muka airtanah yang dangkal. Daerah dengan topografi datar memiliki akuifer yang baik daripada daerah yang topografinya curam. Penemuan di lapangan sejalan dengan pendapat (Purnomo, 2016), air pada permukaan datar menjadi lebih mudah meresap ke dalam tanah dibanding dengan permukaan yang miring. Permukaan datar menjadikan air mempunyai kesempatan yang lebih lama untuk menerobos melewati celah tanah dan bebatuan, sementara pada permukaan miring air cenderung menjadi aliran permukaan.

Material penyusun setiap jenis tanah juga berbeda, sehingga mempengaruhi tekstur, struktur, dan kedalaman tanah. Analisis tekstur tanah tidak dilakukan secara detail pada penelitian ini. Secara umum melalui analisis tersebut dapat diketahui kemampuan tanah dalam menyerap, menyimpan, dan mengalirkan air hujan yang jatuh ke setiap permukaan satuan bentuklahan. Kedalaman tanah juga mempengaruhi banyaknya jumlah atau ketersediaan air yang tersimpan di dalam tanah. Perbedaan kuantitas dan kualitas ketersediaan air, sering disertai dengan perubahan fisik dan kimia atribut tanah, sehingga hal ini membuat berbagai jenis spesies menempati bentuklahan yang berbeda (El-Keblawy, Abdelfattah, \& Khedr, 2015).

Jenis tanah pada wilayah kajian berupa dominan lempung (clay) dapat mempengaruhi kemampuan tanah menahan air. Tanah di DAS Bompon memiliki ketebalan hingga lebih dari empat meter, bahan organik yang rendah, dengan material penyusun dasar dan permukaan berupa lempung disertai material alterasi hasil proses intrusi (Masruroh, Sartohadi, \& Setiawan, 2016). Lempung memiliki daya adsorbsi kecil dan daya serap air sedang. Sifat partikelnya yang berkristal dan sifat koloid stabil, terbentuk lebih lama serta sukar teruraikan oleh mikroba. Jika jenis tanah pada satuan unit bentuklahan lebih banyak lempung, maka tingkat kerawanan kekeringan dikatakan tinggi. Sebaliknya, jika jenis tanah dengan persentase koloid humus lebih besar daripada koloid lempung maka potensi terjadinya kekeringan termasuk kedalam kelas yang rendah (Puspitorukmin, 2013).

Ketersediaan air berupa airtanah umumnya dipengaruhi oleh faktor geomorfologi. Penelitian yang telah dilakukan oleh Acebes et al. (2010) menyebutkan kemiringan lereng berkaitan dengan kemampuan air hujan yang jatuh ke permukaan untuk meresap ke dalam tanah. Sumur yang sulit ditemui pada satuan bentuklahan merupakan salah satu indikator penentu tingkat kedalaman muka airtanah. Kondisi airtanah di DAS Bompon yang sangat dalam, hingga kedalaman lebih dari 30 meter belum terdapat tanda kemunculan air. Hal ini menguatkan asumsi bahwa daerah yang memiliki kelerengan tinggi atau pada bentuklahan interfluve dan lereng atas perbukitan merupakan daerah yang berpotensi rawan terjadinya kekeringan dengan kategori kelas tinggi.

Bentuklahan yang kelerengannya lebih rendah dikatakan tidak berpotensi mengalami kekeringan dengan kategori tinggi melainkan termasuk ke dalam kategori rendah. Kondisi lainnya pada bentuklahan yang kelerengannya lebih rendah terdapat sumber airtanah, yaitu dengan terlihat sumur pada beberapa rumah warga. Beberapa sumur tersebut mengindikasikan bahwa adanya keterdapatan airtanah di wilayah tersebut. 
Kondisi nyata di lapangan sesuai dengan yang dijelaskan oleh Bromley, Brouwer, Barker, Gaze, \& Valentine (2018) dimana posisi batuan yang rendah lebih basah dan lebih dingin daripada posisi relief yang tinggi.

\section{Kesimpulan}

Pendekatan bentuklahan DAS Bompon menunjukkan kelas kerawanan kekeringan di setiap satuan bentuklahan dengan tiga kelas yaitu tinggi, sedang, dan rendah. Kelas dengan kerawanan yang tinggi terdapat pada bentuklahan interfluve dan lereng atas perbukitan. Bentuklahan lereng tengah perbukitan dan lereng bawah perbukitan berada pada kelas dengan kerawanan yang rendah. Kelas dengan kerawanan kekeringan yang rendah berada pada bentuklahan lereng kaki koluvial dan dataran aluvial. Kekeringan ditandai dengan keberadaan mataair yang hanya muncul pada bagian tekuk lereng atau transisi pada bentuklahan.

Berdasarkan hasil yang diperoleh, penggunaan pendekatan geomorfologi untuk penentuan tingkat kekeringan efektif diterapkan karena variasi morfologi suatu wilayah mempengaruhi tingkat kekeringan daerah tersebut.Penggunaan metode untuk kajian kekeringan dengan skala detail baik secara kualitatif dan kuantitatif perlu dilakukan lagi untuk menemukan perkembangan metode yang tepat dalam melakukan analisis kajian kekeringan dari segi sosial. Selain itu, pemanfaatan data spasial yang memiliki panjang saluran dengan sensitivitas lebih baik terhadap kekeringan dapat digunakan agar menghasilkan iinformasi geospasial lebih akurat.

\section{Ucapan Terimakasih}

Ucapan terimakasih tak terhingga kepada Dr. rer.nat Muhammad Anggri Setiawan, M.Si., dan Dr. Djati Mardiatno,
M.Si., yang telah memberikan ide, masukan dan arahan. Terimakasih kepada Lembaga Pengelola Dana Pendidikan (LPDP), yang telah memberikan bantuan biaya selama penulisan. Ucapan terimakasih juga disampaikan kepada seluruh Tim Peneliti Kelompok Transbulent.

\section{Daftar Pustaka}

Acebes, P., Traba, J., Peco, B., Reus, M. L., Giannoni, S. M., \& Malo, J. E. (2010). Abiotic gradients drive floristic composition and structure of plant communities in the Monte Desert. Revista Chilena de Historia Natural, 83(3), 395-407.

Bromley, J., Brouwer, J., Barker, A. P., Gaze, S. R., \& Valentine, C. (2018). The Role Of Surface Water Redistribution In An Area Of Patterned Vegetation In A Semi-arid Environment, South-west Niger. Journal of Hidrology, 198, 1-29.

Budiarta, I. G. (2014). Analisa Kemampuan Lahan untuk Arahan Penggunaan LahanPAda Lereng Timur Laut Gunung Agung Kabupaten Karangasem. Media Komunikasi Geografi, 15(1), 19-31.

Dibyosaputro, S. (2001). Survei dan Pemetaan Geomorfologi. Yogyakarta: Departemen Pendidikan Nasional.

El-Keblawy, A., Abdelfattah, M. A., \& Khedr, A. (2015). Relationships between Landforms, Soil Characteristics and Dominant Xerophytes In The Hyper-arid Northern United Arab Emirates. Journal of Arid Environment, 117, 2836.

Hadi, A. P. (2012). Penentuan Tingkat Kekeringan Berbasis Analisa Citra Aster dan Sistem Informasi Geografis. Majalah Geografi Indonesia, 26(1), 01-26.

Liu, W. ., \& Kogan, F. N. (1996). Monitoring Regional Drought Using the Vegetation Condition Index. International Journal of Remote Sensing, 17, 2761-27-82.

Masruroh, H., Sartohadi, J., \& Setiawan, M. A. (2016). Membangun Metode 
Identifikasi Longsor Berbasis Foto Udara Format Kecil di DAS Bompon, Magelang, Jawa Tengah. Majalah Geografi Indonesia, 30(2), 169-181.

Mishra, A., \& Singh, V. (2010). A Riview of Drough Concept. Journal of Hidrology, 391(1-2), 202-216.

Purnomo, A. (2016). Geografi Fisik. Yogyakarta: Penerbit Ombak.

Puspitorukmin, A. (2013). Kajian Geomorfologi untuk Analisis Potensi Kekeringan Daerah Istimewa Yogyakarta. Universitas Gadjah Mada.

Raharjo, P. D. (2010). Teknik Penginderaan Jauh dan Sistem Informasi Geografis untuk Identifikasi Potensi Kekeringan. Makara Teknologi, 14(2), 97-105.

Sadri, S., \& Burn, D. . (2012). Nonparametric Methods for Drought Severity Estimation at Ungauged Sites. Water Resources Management, 48, 12-25.

Sutikno. (1989). Kajian Bentuklahan Untuk Permintakatan Sistem Penyediaan Air Bersih di DAS Serang Kulonprogo. Universitas Gadjah Mada.

Wang, A., Lettenmaier, D. P., \& Sheffield, J. (2011). Soil Moisture Drought in China, 1950-2006. Journal of Climate, 24, 3257-3271. 